浜田日佐夫

〔昭和”39 年 12 月 12 日受稿〕

\section{楮言}

第 1 編に於ける海猉脳の実験を通じ, RNase の 脳実質内，又は脳脊䯣液導入は，脳神経細胞内人の RNase の浸入と共に. 細胞の RNA が消化される 事が明らかにされた，海猽は静止状態を続り餌を取 らなくなるので，RNA の消失は神経細胞の機能低 下を起すすのと思われた。然し，海舅は更に高次の 神経細胞の機能を分析するには不適である．前実駼 に於いて, 著者は脳脊髄掖中への RNase 注入は, 脳実質内注入と全く同様の細胞の変化之, 症状を引 起す事を知つた。 との事は同様の実験がマウスでも 技術上可能である事を示している，本編に於いては， より精神活動の分析が容易であるマウスに RNase を脳実質内に注入し, 海犋の実験と比較検討した. 即ち RNase 注入後のマウスの状態の観察之共に, ニッスル染色に依る神経細胞の好塩基性の変化に就 いての組織学的観察を行つた. 病理学者は, 普通二 ッスル染色で細胞質の RNA の変化を重要な所見の 一つとして観察して来た。

\section{実験材料，及ひ方法}

材料：マウスは $20 \mathrm{~g}$ 前後の, ddn 純系, 近親交 配のもの60匹を使用した。

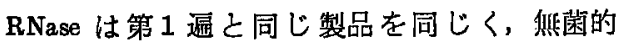
Hanks's solution の溶液として使用した.

方法 : 神経細胞の活動性のテストとしては Swinyard等の方法1), 及び著者等の考按した握カテスト を行なつた。

Test 1. 板乘りテスト，マウスを台の上に乘せて 台の縁から雨後足をはつした時，そのマウスが阿足 を台の上に乘せ得るかどうかを観察する.

Test 2. Righting Test マウスを仰卧位にした時, 正常の位犆に戻るかどうか, 又その反応の遅速を䅐
察する.

Test 3. 橋渡りテスト, あらかじめ空腹状態にし ておいたマウスを，飳箱に橋渡した巾 $5 \mathrm{~mm}$ ，長さ $30 \mathrm{~mm}$ の緣の上を少行させ，步行状態を観察する. Swinyard に従いこの Testに最む重点を置いた。

Test 4. 握力テスト（炉尾，浜田の考案に依る） マウスを金網にとりつかせて，尾をバネのついたツ マミで挾み，そのツマミをバネ秘值絬させて，バ ネ科でマウスの尾を引張り，マウスが引張られる力 に抗し切れなくなつて金網を離す時のバネ科の目盛 を読んで握力の強弱を判定した. マゥスを太さ約 1 $\mathrm{mm}$ の金網にとりつかせて，尾を引張るとマウスは 本能的に引張られる力に抗して，力一杯金網により つき，意識的に金網を放すことはない.

奏際にとの方法でマウスが引張られる力に抗し切 れなくなつて，金網を放す時のバネ科の目盛は，同 一マウスでは大体一定の数価を示す。これ等の事か らこの方法がマウスの握カテストを判定するのに利 用出来ると判断された。握力はバネ科のグラム目盛 に依つて表わされる。

RNase の脳実質内注入法は, 先端の部の太さ $1 / 3$ mm の 2 段針（插図 B ）を用いて，マウスの両目を 結ふ線を底辺とする正三角形の頂点で, 正中綠を少

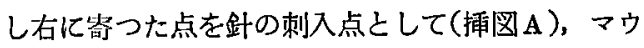
スの脳笑質内に，0.5\%及び $1 \%$ RNase Hanks's solution 1 匹当り $0.05 \mathrm{cc} つ つ$ 注入した. RNase 注入後 6 時間で Test 1.2.3.4.を行い, RNase 注入 前の成績と比較すると共に，直後マウスの頸轩脹を 切断して殺し，速やかに脸を取り出してェタノール 固定, パラフイン包理, ニッスル染色にて組織を観 察した。

对照としては，同様のう法にて，然囷的 Hanks's solution を $0.05 \mathrm{cc}$ 脸内に注入後前記と同椂の倠察 を行なつた。 


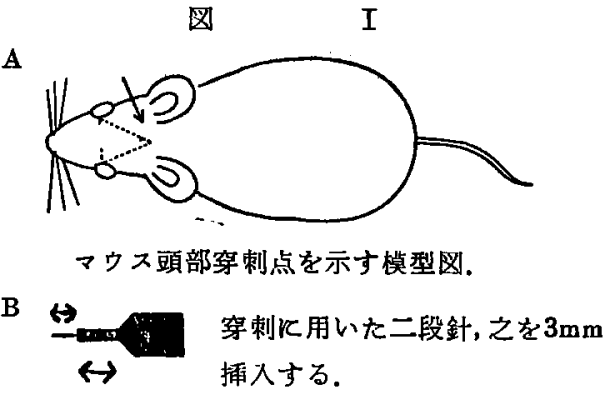

結果

4 つのテストを RNase 敛内注入以前の正常マウ スに施行する之, Test 1.では, マウスを台の上に 乘せて両方の後足を台からはずす様にすると，マウ スは直ぐ台の上へ飛び上る. Test 2では正常のマ ウスは仰臥位にする事自体が困雑であり，仰卧位に し得ても直ちに正常体位に戻る. Test 3 では, 正 常マウスを予じめ空腹にして置き, 巾 $5 \mathrm{~mm}$, 高さ $10 \mathrm{~mm}$, 長さ $30 \mathrm{~mm}$ の木の棒を, 䬺箱化渡し, その 上を歩かすとマウスは木の上で止る事なく棒の上を 歩行する.

Test 4 では正常マウスの握力は $150 \sim 200 \mathrm{~g}$ の範 囲にあり，同一マウスでは略一定の洒を示す。

$1 \%$ RNase $0.05 \mathrm{cc}$ を脳実質内に注入したもの20 匹に於いては，先つ第 1 亿観察された症候は約半数 の11匹に後足の麻癣を認めたが，対照動物にはこの 様な事は認められなかつた。 Test の結果は表Ｉに 見る如く，Test 1 では後脚を台上にあげる事の不 能なむの 3 匹, 麻㾝した後脚をひきつり年ら前足の

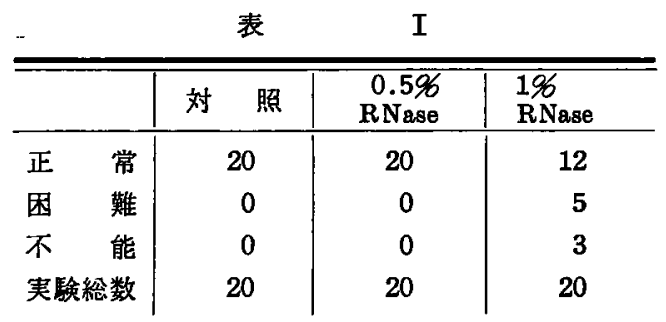

表I $0.5 \%$ 及び $1 \%$ RNase を右大脳実質内K 注射したマウスの板乘りテスト（Test 1)

注射 6 時間後, 0.5\% Rnase t社入した あの及び対照動物では全く変化はなかつた が1\% RNase を注射したものは後股を台上 に引上げるの可成りの困雉を示したもの 5 , 後肢を台上飞引上ごるのが全く不能な あの 3 を認めた。

実験方法：本文參照
みで這い上る事の出来たもの一困難一，5匹，他の マウスでは余り障淂を認めなかつた. Test 2では 们臥位からの体位の復元の不能のものが 1 匹あつた が, これは RNase そのものの作用であつたかどう かは疑問である。 Test 3 に於いては健全に棒を渡 れるものは, 僅かに 3 匹で, 後足の麻㾝が比䩙的軽 度のあのはよろけながながら何んとか渡れる．との 様な状態のものが 7 匹一困難一

後足の麻㾝の為棒の上に立つている事が出来ず前 足で棒にふらら下る様な恰好になり途中で落ちてしま うもの一不能一 8 匹, 始めから全く棒に乗れないも の一完全不能一 3 匹, を認妨た（表II）Test 4 て は表西化示す如く RNase 注入群では握力の減退が

\begin{tabular}{|c|c|c|c|}
\hline & 対 照 & $\begin{array}{l}0.5 \% \\
\text { RNase } \\
\end{array}$ & $\begin{array}{l}1 \% \\
\text { RNase }\end{array}$ \\
\hline 正 & 20 & 17 & 2 \\
\hline 困 & 0 & 3 & 7 \\
\hline 不 能 & 0 & 0 & 8 \\
\hline 完全不能 & 0 & 0 & 3 \\
\hline 実験総数 & 20 & 20 & 20 \\
\hline
\end{tabular}

表 II $0.5 \%$ 及び $1 \%$ RNaseを大脳右半球実質内r 注入山たマウスの橋渡りテスト（Test 3)

注入 6 時間後, 対炤の Hanks 氏液注入 動物では 1 例す変化を示さない. $0.5 \%$ RNase 注入群では, よろけるるの3匹を認 めたのみであるか1\% RNase 注入では完全 飞橋汇乘る事の出来ないすの 3 匹，途中で 落ちたもの 8 匹，よろけながら何とか渡れ るもの 7 匹，残りの 2 匹正常の行動をと つた.

\begin{tabular}{|c|c|c|c|}
\hline & 対 照 & $\begin{array}{c}0.5 \% 6 \\
\text { RNase }\end{array}$ & $\begin{array}{l}1 \% 6 \\
\text { RNase }\end{array}$ \\
\hline $50 \mathrm{~g}$ 以下 & 0 & 0 & 7 \\
\hline $50-100 \mathrm{~g}$ & 0 & 0 & 10 \\
\hline $100-150 \mathrm{~g}$ & 3 & 6 & 3 \\
\hline $150-200_{t}$ & 17 & 14 & 0 \\
\hline 実 験 総 & 20 & 20 & 20 \\
\hline
\end{tabular}

表而 $0.5 \%$ 及び $1 \%$ RNase 右大脳半球実質内に 注入したマゥスの提力試験（Test 4)

注入 6 時間後 $0.5 \%$ RNase 注入では 20 匹中 6 匹亿軽度の握力の低下を認めたが1 \%6 RNase 注入動物では全例飞於いて，7 匹には著るしい握力低下を認めた。 実験方法：本文参照 
顕著で，力の衰えを示さなかつたものは 3 匹で，他 の17匹は程度の差はあるが力の減退が明らかに認め られた.

次に $0.5 \%$ RNase $0.05 \mathrm{cc}$ を脳実質内に注入した もの20匹に於いては，総じて対照例のもの之变らず Test 1.2 亿関しては，殆んど異常を認めず（表 I）Test 3 に於いては，5匹に棒を渡る際に少し よろめくのが認められた（表II）.

Test 4 於いても軽度に力の減退を見るものが対 照に比して多かつた.（表正）

対照として無菌的 Hanks 液 $0.05 \mathrm{cc}$ を注入した あの20匹に於いては全く注入以前と変らず Test 1 ， 2. 3. 4 共全マウスに異常を認めなかつた.

組織学的観察は RNase 注入 6 時間後の脳を，小 脳 第 V脳室底を通る断面，及び乳頭体を通る前額 断面で前記の方法に従つて, ニッスル染色を施し， 諸神経細胞を観察した.

1 \% RNase Hanks's solution を注入したすので は Test 1.2.3.4. 共異常を認めなかつた 2 匹を 除いて，残りの18匹に於いて，小脳の Purkinje 細 胞及び大脳の諸神経細胞を含む殆んど全ての脳細胞 のニッスル小体の著明な減少を認めた。

0.5\% RNase Hanks's solution を注入したもので は，20匹中 7 匹に小脳の Purkinje 細胞その他の神 経細胞に二ッスル小体の減少及び消失を認めた. 大 䏚及び脳幹の神経細胞も一部に著明なニッスル小体 の減少を認める所もあつたが, 総じて程度は怪かつ た.

一方対照例の組織では, 穿刺部位の軽度の反応を 除き如何なる神経細胞のニッスル小体にあ何ら異常 を認めなかつた。

\section{総括, 並ひに考案}

脳神経組織に於ける RNAに就いては，最近特 亿注目を浴び，その研究2)-7)も数多くなされており， Hyden 等は活発に活動した時には，脊䯣の前角細 胞の細胞質の RNA 含量が減少し8), 又一方蝸牛神 経核細胞の聴覚の刺戟の後には，RNAの含量に同 し様な減少が見られると報告している92. 著者の実 験より得た結果では, マウス脳神経細胞も海猽の場 合之同様 RNase に依り，その RNA の低下を来し， 脳神経細胞の RNA が減少, 或は消失すれば, その
運動機能に著明な障碍を来たす事を示した．特に 1 \% RNase を $0.05 \mathrm{ce}$ 脳実質内注入したものでは， 組織学的に脳神経細胞の著るしい RNA の減少, 或は消失を認め，而屯運動神経汇関する機能の減退 が著明に認められた，同じ様な実験で RNA の減少 が少なく，而も運動テストにあまり変化の認められ なかつたすのもあつた事低，注入後の液の漏出，そ の他の実験方法の不手際偖るすの之考えられる. 4 つのテストを通じていえる事は，RNA が少くな ると全般的に運動機能が障碍されるという事である。 然し，動物が小さく， RNase を脳の限局した一部 分に作用させる事が出来ないために各神経核の機能 を，てれ等の結果より分析する事は出来ない，第 1 編, 及び第 2 編の実験を通じて RNA が神経細胞の 機能の発現に重要な物質である事は, 最早疑問の余 地がない，現在知られている一般体細胞に於ける RNA の主作用は蛋白合成である10)-12）事から考え ると脳に於ける RNA る蛋白合成に関係している と考へてよいであろう．若しそうであれば神経細胞 は，蛋白合成という過程を通してて諸種の機能，即ち 記憶, 運動の調節等を果しているのかむ知れない。 然し，との事を明らかにするためには，神経細胞の 蛋白合成に就いて，もつと詳しく知らなりればなら ない.

\section{結語}

1）マウス脳に RNase を注射すると各種神経細 胞の RNA が減少，或は消失する。

2） 196 RNase 0.05cc をマウスの脳内に注入す れば，著明な運動障碍を起す，運動障碍の程度は脳 神経細胞の RNA の減少像之平行関係にある.

3）以上の事実よりマウスの運動機能に関係する 神経細胞の働きは，それが保有する RNA 量と深い 関係汇あるものと結論されれた。

擱筆するK臨み，終始御愁篤なる御指導並びに御 校閲を睗りました恩師妹尾教授並びて児玉教授に深 甚なる謝意を表します。

併せて常飞御厚意あふれる御教示を戴きました本 病理学教室小田助教授並びに教室員各位に深謝し又 色々と御親切な御援助を下さつた本学精神神経科大 月满師, 立びに三井先生に厚く御礼用し上けます。 
1) E. A. Swinyard, W. C. Brown, L. S. Goodman,: J. Pharmacl. and Exp. Therap. 106. 319 (1952)

2) H. von Foerster,: Das Gedachtnis (Deuticke, Vieuna, 1948)

3) H. Hyden,: Biochemistry of the Central Nervous System, vol. 3 of Proc. 4th Intern. Congr. Biochem. (Pergamon, New York, 1960)

4) S. Brattgard,: Acta Radiol. Scand. Suppl. 96 (1952)

5) R. Thompsom and J. McConnell,: J. Comp. and Physio. Psyco. 48,

6) J. McConnell, A. L. Jacobson, D. P. Kimble, ibid. 52, 1 (1955); E. Frnhart and C. Scherrick,: Personal comunication forward by J. McConell.

7) J. B. Best,: Federation Proc. 19, 24 (1960)

8) H. Hyden,; Acta Physiol. Scand. Suppl. 6, (1943)

9) Hamberger, C. A. and H. Hyden,: Acta otolaryngol. Suppl. L XI 61, (1945)

10) Caspersson, T.: Naturwiss 29, 33, (1942)

11) Brachet, J.: Chemical Embryology (New York : Interscience Publishers. Inc.) (1950)

12) Allfrey, V. G., Daly, M. M., and Mirsky, A. E.: J. Gen. Physiol. 37, 157 (1953)

\title{
On the Relationship Between Function and Ribonucleic Acid of Cerebral Ganglion Cell
}

\section{Part 2. Relatioship of RNA to the motor function of mouse brain} By

\author{
Hisao Hamada \\ Department of pathology, Okayama University Medical School
}

(Director : Prof. Satimaru Seno)

\section{Author's Abstract}

In a previous paper it was revealed that either the injection of RNase directly into the cerebral tissue or into liquor by cisternal puucture caused similar changes on tbe reduction of RNA level of the cerebral ganglion cells in the brain of guinea pigs, and the behavioral changes of the animals.

It was thought that the same method might also be applicable to the mouse in which further paychological and behavioral analysis are more readily accomplished.

In the present experiment RNase was injected directly into cerebral tissue of the mouse and the motor function of the mouse brain was analyzed. As the result it was found that on the injection of $0.05 \mathrm{ml}$ of $1 \%$ RNase directly into the cerebral tissue of the mouse, severe motor disturbance was induced, and in addition, the degree of the functional disturbance paralleled with the decreased leve of RNA on the cerebral ganglion cells. 
浜田論文附図（2編）

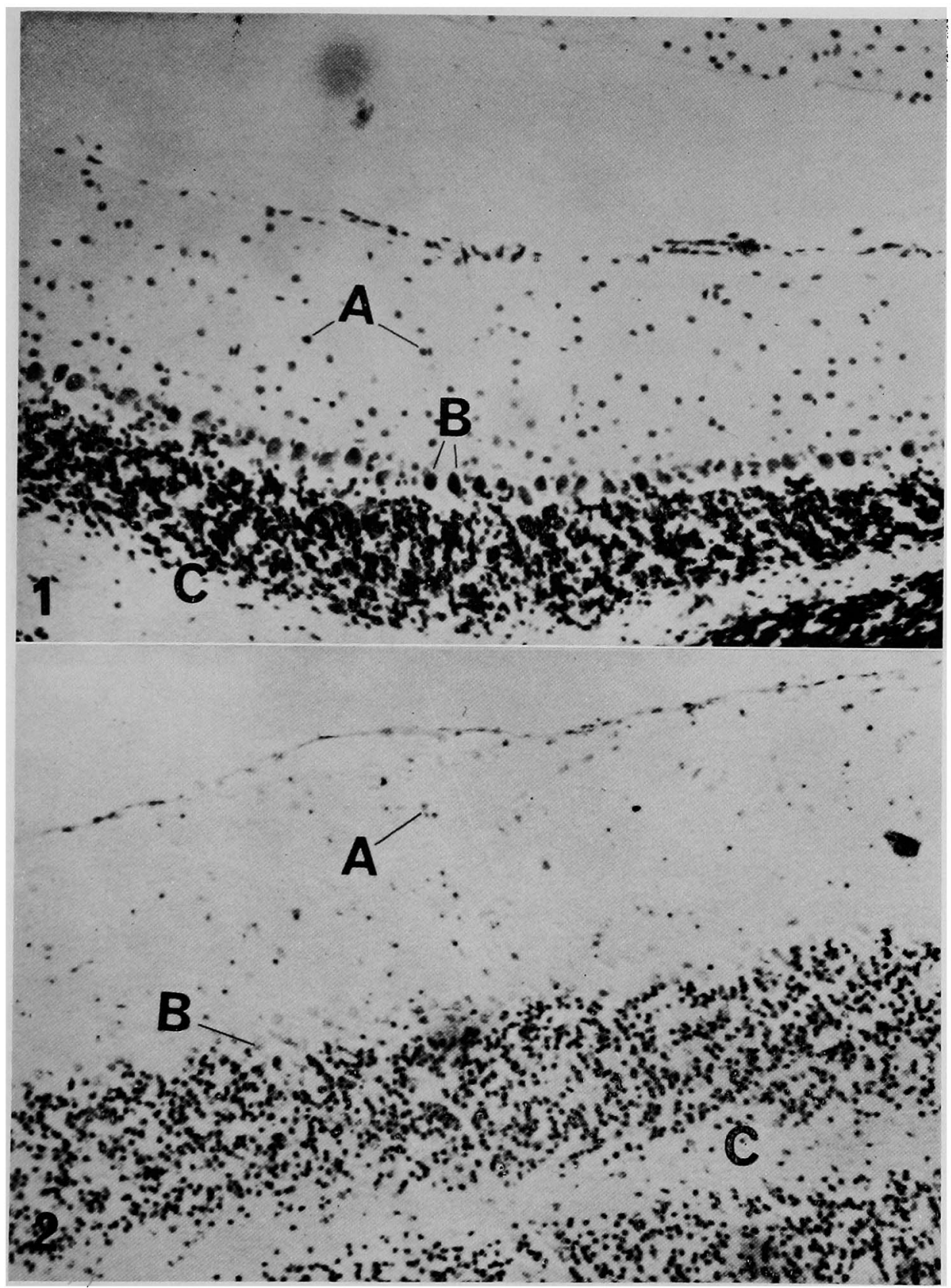

1. 対照動物の小脳, Hanks 液 $0.05 \mathrm{cc}$ 脳内注入 6 㭙問後の切片各細胞層は健常なものと变らない。
A. 分子尿の細胞
B. プルキンエ細胞
C. 顆粒層の縕胞
エタノール固定
ニッスル染色 $\Upsilon_{100}$
方法：本文参照

2. $1 \%$ RNase $0.05 \mathrm{cc}$ を脳内注入 6 㭙間後の小脑, 各細胞の染色が著るしく娍少している. 特にブルキン 工細胞は大きく，1の対照と比してその染色性の低下を認める事が出来る.
A.B.C.は1飞同じ
方法 本文参照
エタノール固定
ニッスル染色 $\times 100$ 


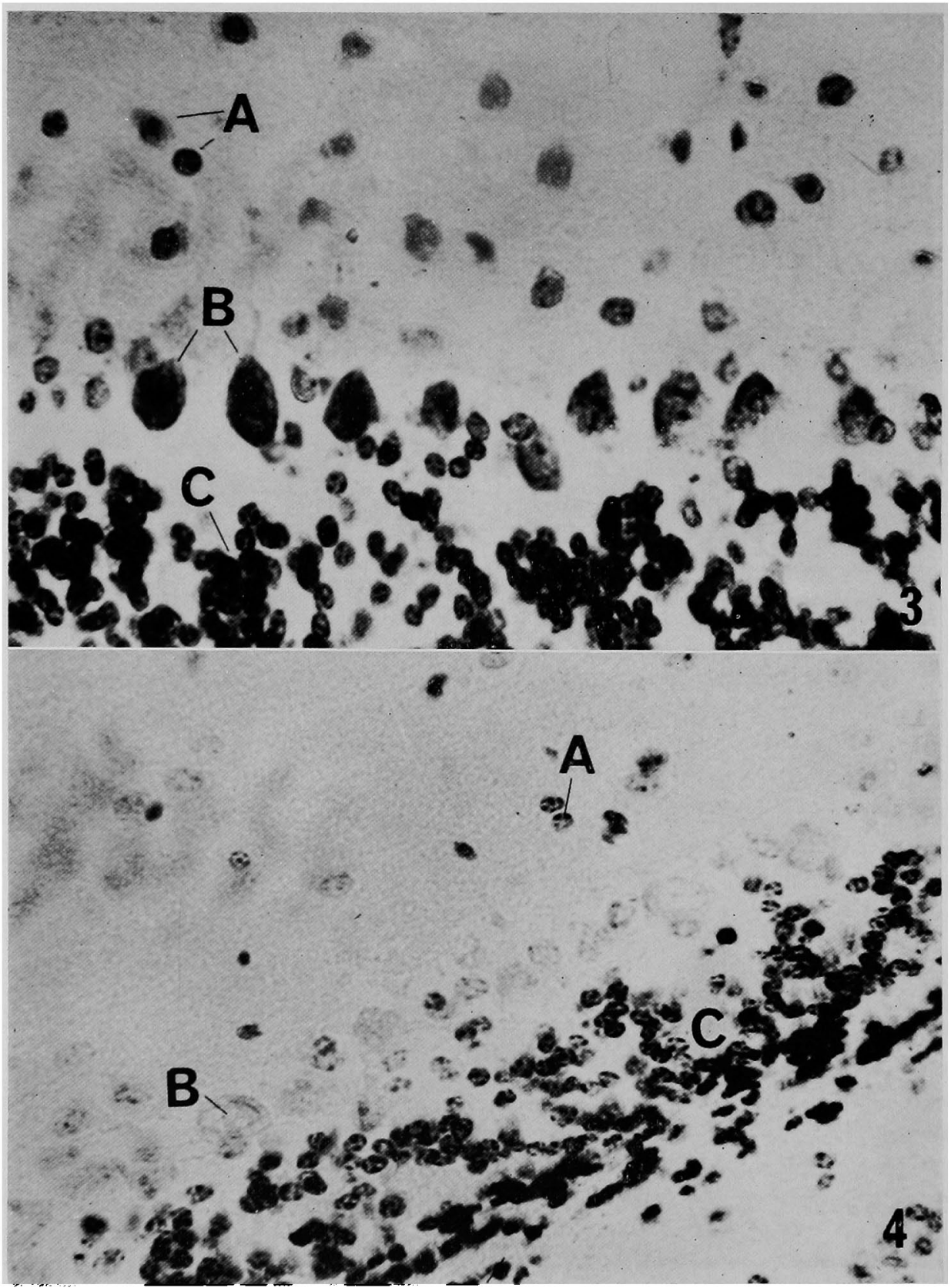

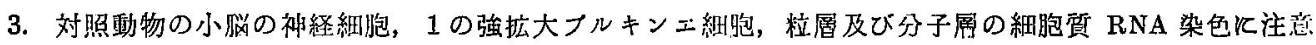
1 と同一処理
A. 分子尿の細胞
B. ブルキンエ細胞
C. 顆粒層の縕脢
エタノール固定
ニッスル染色 $\times .400$

4. RNase 処理後の小脳強㹡大写真 2 のものと同様な処理を行なつたもの、ブルキンエ細胞は殆んど染色 性を失ひ，核小体む染色されなくなつている。顆柆層及び分子層の細胞は核のみ染色され，細胞質は砝 んど染色されない，方法 本文参照 A. B.C. は 3 と同じ エタノール固定 ニッスル染色 $\times 400$ 
浜田論文附図。

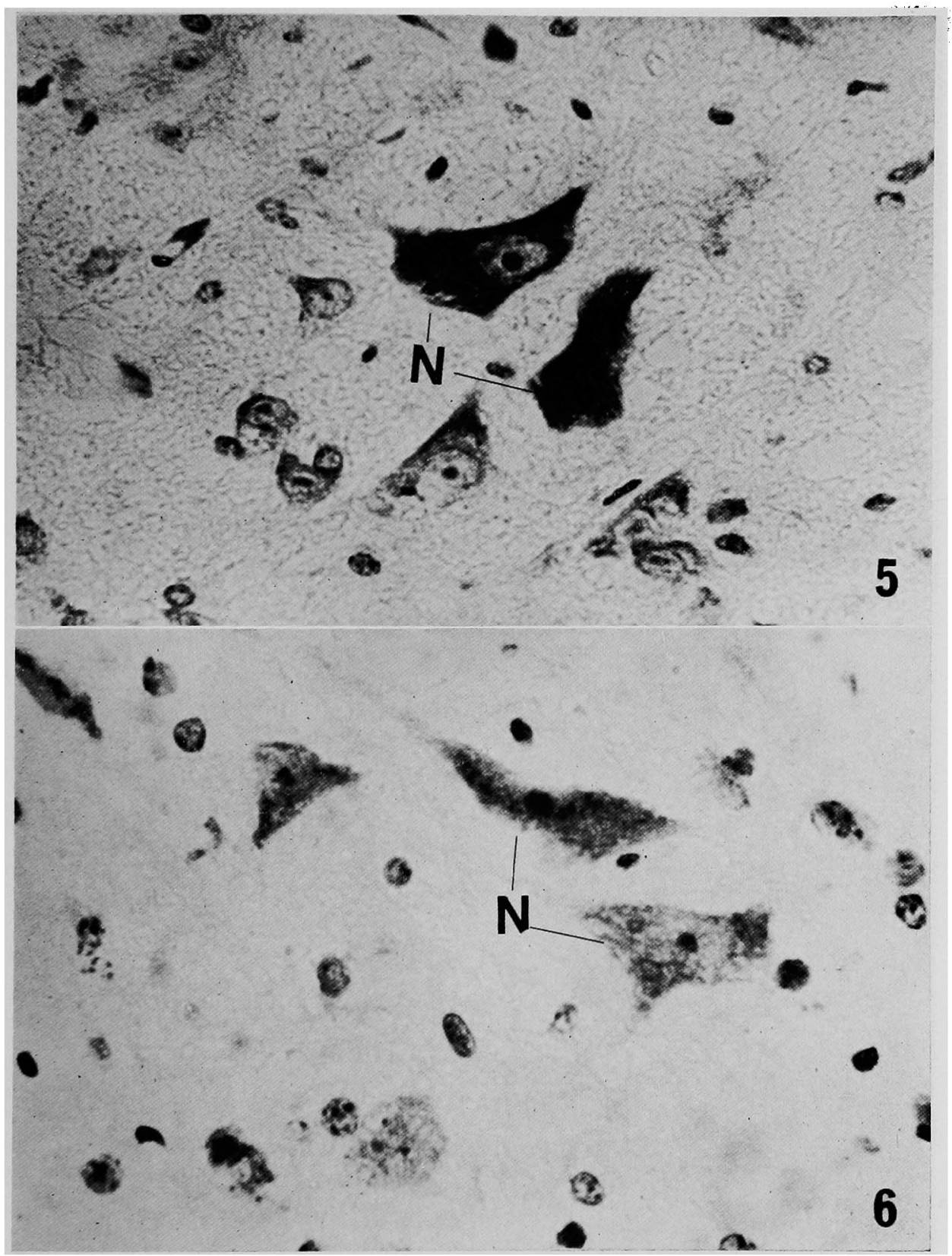

5. 対照動物脳橋の運動神経細胞, 1 の動物と同一処理 多量のニッスル小体をもち核小体明瞭

$N$ ：運動神経細胞 エタノール固定 ニッスル染色 $\times 400$

6. RNase 処理動物の脳橋の運動神経細胞, ニッスル小体の染色性低下と，核の染色不良状態を示す. 2 と同一処理を行なつたもの
$\mathrm{N}$ : 速動神経細咆
エタノール固定
ニッスル染色 $\times \mathbf{4 0 0}$ 
浜田論文附図

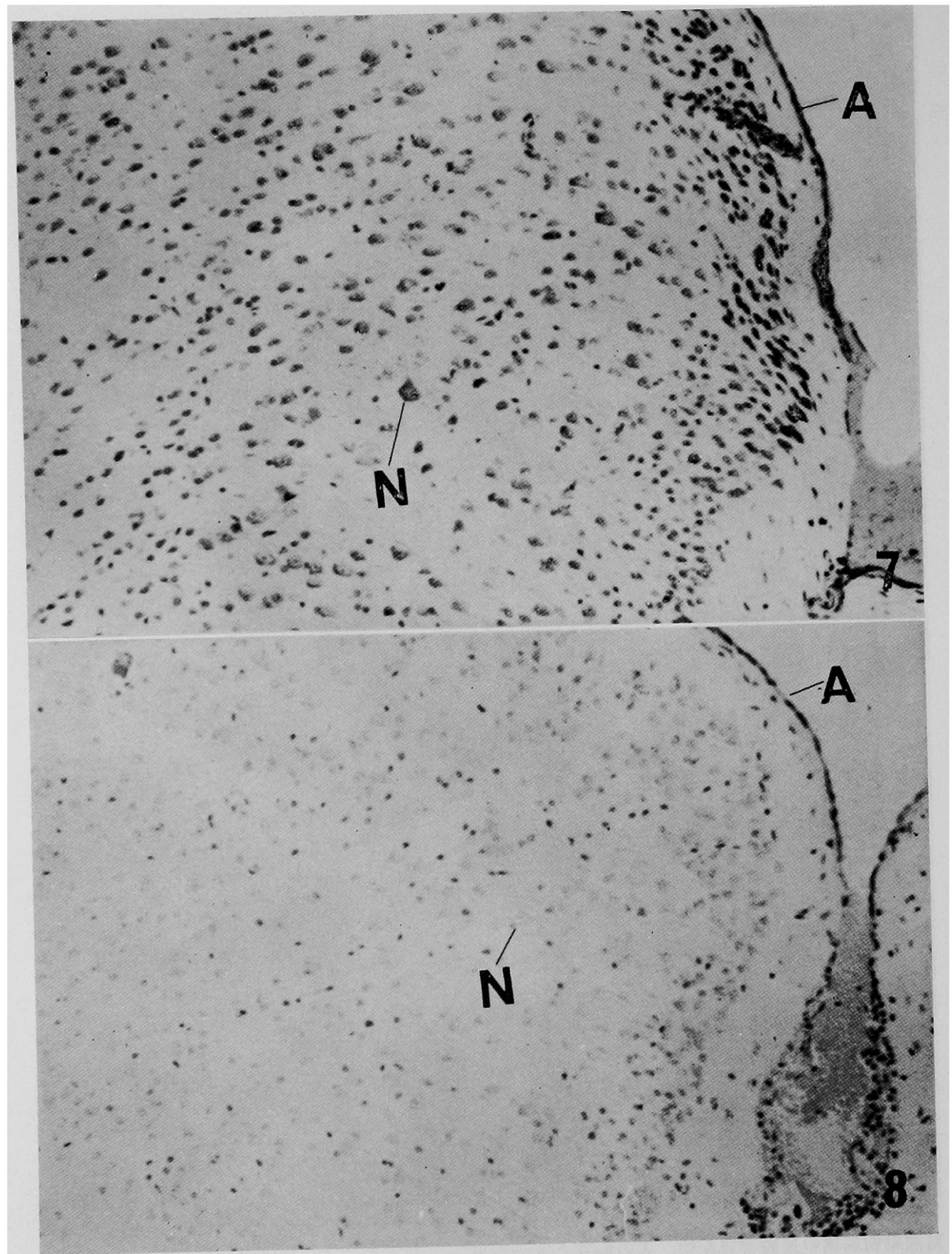

7. 対照功物の大脳皮澌，弱拉大写真全体の染色性がよくかかる。

処理は 1 と同一

A：脳軟膜

$\mathrm{N}$ : 神経細胞

エタノール固定

ニッスル染色 $\times 100$

8. RNase 処理動物の大脳皮質弱讼大, 全体として染色性の減少がよくわかる. 処理は 2 と同一
A：脳㳄膜
$\mathrm{N}$ : 神経細胞
エタノール固定
ニッスル染色 $\times 100$ 
浜 田 論 文 附 図

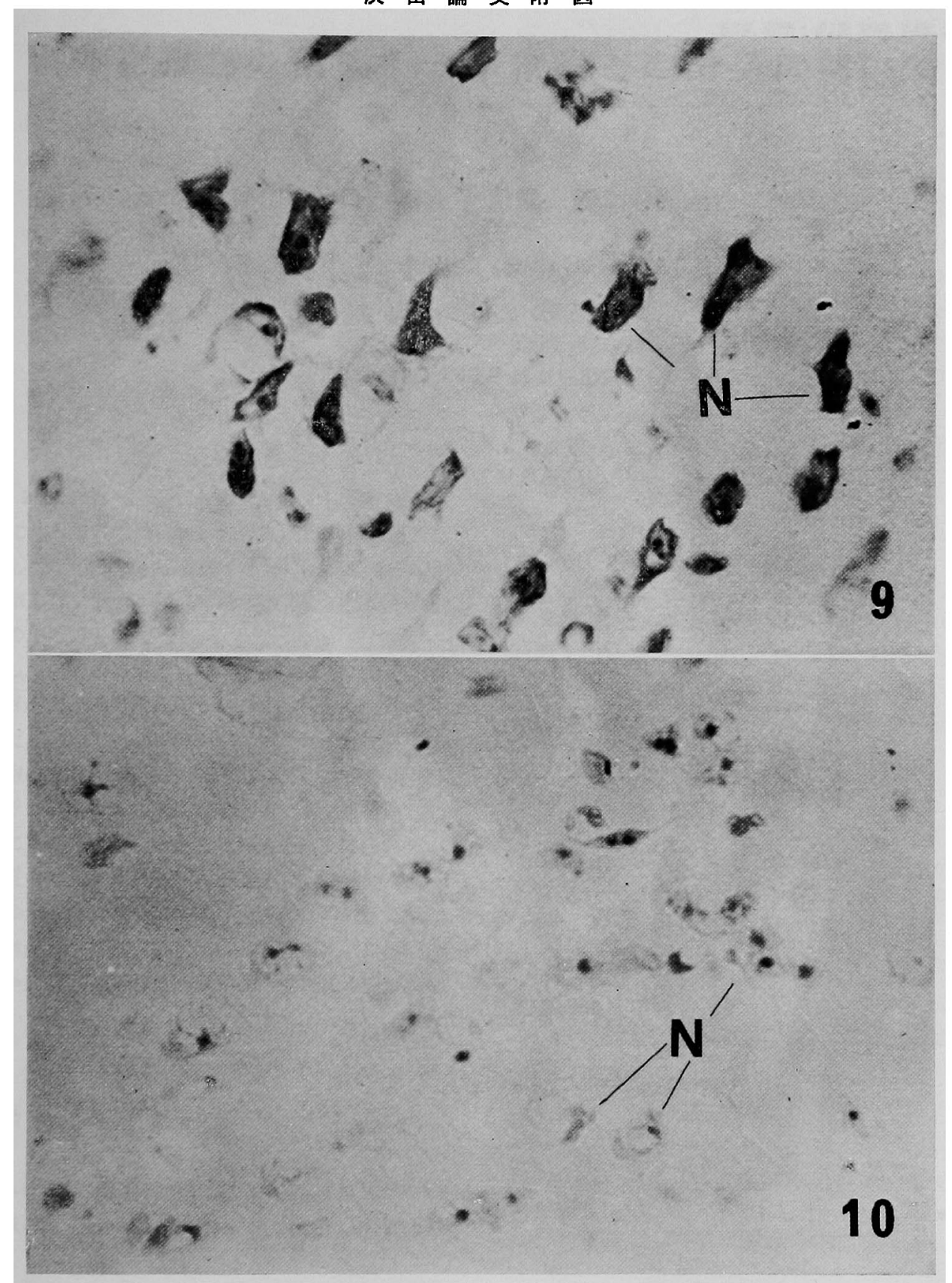

9. 対照動物の大脸皮質神経細胞 処理は 1 と同じ，濃染された細胞質を認め正常胹物のものと変りない. $\mathrm{N}$ : 神経絊胞 エタノール固定 ニッスル染色 $\times 400$

10. RNase 処理動物の大脳皮質神経細胞，処理は 2 と同じ，細胞質の染色性低下と共に案胞变性が認めら れる.

$\mathrm{N}$ : 神経細胞エタノール固定 ニッスル染色 $\times 400$ 